\title{
FORMULATION AND EVALUATION OF TRANSPARENT SOAP FROM BONE COW COLLAGEN (Bos sp.) AS MOISTURIZER
}

\section{FORMULASI DAN EVALUASI SABUN TRANSPARAN DARI KOLAGEN TULANG SAPI (Bos sp.) SEBAGAI PELEMBAB}

\author{
Nilsya Febrika Zebua ${ }^{1 *}$, Sudewi ${ }^{1}$, Masrina Prihatini1 \\ Fakultas Farmasi Universitas Tjut Nyak Dhien \\ Jl. Gatot Subroto, Gang Rasmi, No.28, Sumatera Utara, Medan, 20123 \\ *e-mail : nilsya.zebua@gmail.com
}

\begin{abstract}
Collagen is one of the proteins that make up the body or the organic structure that builds bones, teeth, joints, muscles, and skin. Collagen is very often used by the community because it is to maintain healthy skin and maintain skin elasticity. This study aims to determine collagen from bovine bones can be formulated into transparent soap preparations. Bovine bone collagen (Bos sp.) was extracted by immersion using $1 \mathrm{~N} \mathrm{NaOH}$. The production of transparent soap formulas in several concentrations is $0.5 \%, 1 \%, 2.5 \%$, and $5 \%$ collagen. The bovine bone collagen yield was obtained $27.5 \%$. Collagen in a variety of concentrations produces different colors and the ability to moisturize the skin. Bovine bone collagen (Bos sp.) was formulated in transparent soap preparations from bovine bone collagen (Bos sp.) with a concentration of $0.5 \%$ including the category "moist" and transparent soap preparation from bovine bone collagen (Bos sp.) $1 \%, 2.5 \%$, and $5 \%$ including the category of "very humid" and the results of testing on volunteers showed that transparent soap from collagen in bovine bone (Bos sp.) did not cause irritation.
\end{abstract}

Keywords: Bovine (Bos sp.), Bone, Collagen, Transparent Soap, Moisturizer.

\begin{abstract}
ABSTRAK
Kolagen adalah salah satu protein penyusun tubuh atau struktur organik pembangun tulang, gigi, sendi, otot, dan kulit. Kolagen sangat sering digunakan masyarakat karena demi menjaga kesehatan kulit dan memelihara elastisitas kulit. Penelitian ini bertujuan untuk mengetahui kolagen dari tulang sapi dapat diformulasikan kedalam sediaan sabun transparan. Kolagen tulang sapi (Bos sp.) diekstraksi dengan cara perendaman menggunakan $\mathrm{NaOH} 1 \mathrm{~N}$. pembuatan formula sabun transparan dalam beberapa konsentrasi yaitu $0,5 \%, 1 \%, 2,5 \%$, dan $5 \%$ kolagen. Rendemen kolagen tulang sapi diperoleh $27,5 \%$. Kolagen dalam sediaan dengan variasi konsentrasi menghasilkan warna dan kemampuan melembabkan kulit yang berbeda. Kolagen tulang sapi (Bos sp.) yang diformulasikan dalam sediaan sabun transparan dari kolagen tulang sapi (Bos sp.) dengan konsentrasi yaitu 0,5\% termasuk kategori "lembab" dan sediaan sabun transparan dari kolagen tulang sapi (Bos sp.) 1\%, 2,5\%, dan 5\% termasuk kategori "sangat lembab" dan hasil pengujian terhadap sukarelawan menunjukkan bahwa sabun transparan dari kolagen tulang sapi (Bos sp.) tidak menyebabkan iritasi.
\end{abstract}

Kata kunci: Sapi (Bos sp.), Tulang, Kolagen, Sabun Transparan, Pelembab. 
PENDAHULUAN

Sabun digunakan sebagai bahan pembersih kotoran, terutama kotoran yang bersifat lemak dan minyak karena sabun berfungsi sebagai emulgator, dapat mengemulsikan lemak atau minyak. Sabun padat yang beredar dipasaran saat ini dibedakan menjadi tiga jenis yaitu sabun opaque, translucent, dan transparan. Sabun transparan memiliki tampilan yang sangat menarik, berkelas dan mewah sehingga membuat sabun transparan dijual dengan harga yang relatif mahal, dan dapat dijadikan cinderamata atau souvenir yang memberikan kesan yang sangat unik dan memberikan tampilan yang ekslusif (Widyasanti dan Hasna, 2016).

Pada umumnya, kolagen berasal dari bahan baku tulang dan kulit mamalia seperti sapi dan babi. Tulang sapi merupakan bahan dari sisa olahan bahan makanan yang sudah tidak terpakai dan memiliki nilai ekonomis yang rendah. Tulang yang baik digunakan sebagai sumber kolagen adalah tulang yang kompak, karena komposisinya relatif stabil dan mudah dipisahkan dari jaringan yang ada disekitarnya. Tulang sapi memiliki kandungan kolagen didalamnya. Tulang kaya akan senyawa protein khususnya protein kolagen yang memiliki potensi untuk diproses menjadi bahan baku tambahan untuk kecantikan dan peremajaan kulit (Alhana, et al., 2015, Nagai, et al. 2004).

Kolagen merupakan komponen struktural utama dari jaringan ikat putih yang meliputi hampir $30 \%$ dari total protein pada jaringan dan organ tubuh vertebrata dan invertebrata. Pada mamalia kolagen terdapat di kulit, tendon, tulang rawan dan jaringan ikat. Kolagen diproduksi secara alami oleh tubuh manusia untuk menjaga elastisitas dan kekenyalan kulit, namun pada usia 40 tahun tubuh akan mengalami penurunan produksi kolagen sehingga perlu asupan dari luar tubuh (Harris, 2015). Pembuatan sabun kolagen merupakan hal yang menarik karena kolagen berperan dalam kesehatan kulit, sehingga konsentrasi kolagen yang ideal dalam pembuatan sabun transparan yang akan dibahas dalam penelitian ini.

\section{METODE PENELITIAN}

\section{Alat yang digunakan}

Alat yang digunakan pada penelitian ini adalah neraca digital MARK-M5-ION, oven (Memmert), termometer, refrigator (Hitachi), blender (Panasonic), hot plate (Nuova), stopwatch, Spektrofotometer Fourier Transform Infrared (Shimadzu), Skin moisture analyzer (SG-5D), pH meter (ATC), magnetic stirer with heater 79-1, dan alat-alat gelas laboratorium.

\section{Bahan yang digunakan}

Bahan yang digunakan pada penelitian ini adalah tulang sapi (Bos sp.), minyak kelapa sawit, $\mathrm{NaOH}$, gliserin, alkohol 96\%, gula, TEA (Trietanolamin), parfum (Oleum citri), $\mathrm{KOH}, \mathrm{HCl}$, dapar fosfat dan akuades.

\section{Pengolahan}

Tulang sapi yang segar bagian paha seberat 2.250 gram dicuci dan dibersihkan dari sisa-sisa lemak atau daging yang masih menempel pada tulang. Kemudian didegredesing pada suhu $80^{\circ} \mathrm{C}$ selama 3 jam. Dipotong setebal $\pm 4 \mathrm{~cm}$, dibersihkan dan ditiriskan. Kemudian direndam dalam $\mathrm{NaOH} 1 \mathrm{~N}$ selama 10 hari. Proses selanjutnya yaitu penetralan dengan cara tulang sapi dicuci dengan akuades hingga $\mathrm{pH}$ netral yaitu 7 , selanjutnya dikeringkan kedalam oven dengan suhu $40^{\circ} \mathrm{C}$ selama 4 hari. Sampel dihaluskan dengan menggunakan blender, kemudian diayak menggunakan mesh 100 dan diperoleh kolagen tulang sapi (Nagai dan Suzuki, 2000). Kemudian dilakukan analisis gugus fungsi dengan FT-IR dan pembuatan sabun transparan dari kolagen tulang sapi.

Formulasi sabun mengikuti fomula Williams dan Schmitt (2002) yaitu dengan modifikasi penambahan konsentrasi kolagen tulang sapi (Bos sp.) yaitu $\mathrm{F} 1$ (tanpa penambahan kolagen tulang sapi), F2 (0,5\%), F3 (1\%), F4 (2,5\%), dan F5 (5\%).

\begin{tabular}{|c|c|c|}
\hline \multirow[t]{7}{*}{$\mathrm{R} /$} & $\begin{array}{l}\text { Minyak kelapa sawit } \\
\mathrm{NaOH} 5 \mathrm{~N}\end{array}$ & $\begin{array}{l}20 \mathrm{ml} \\
15 \mathrm{ml}\end{array}$ \\
\hline & Gliserin & \\
\hline & Alkohol 96\% & $15 \mathrm{ml}$ \\
\hline & Sukrosa & 15 gram \\
\hline & TEA & $5 \mathrm{ml}$ \\
\hline & Kolagen & $X$ \\
\hline & Parfum (Oleum citri) & qS \\
\hline
\end{tabular}

\section{Pembuatan sabun padat transparan}

Minyak kelapa sawit sebanyak $20 \mathrm{ml}$ dimasukkan kedalam beaker glass $250 \mathrm{ml}$ diatas hot plate dengan suhu $70-80{ }^{\circ} \mathrm{C}$. Kemudian ditambahkan sedikit demi sedikit $15 \mathrm{ml} \mathrm{NaOH} 5 \mathrm{~N}$ 
sambil dilakukan pengadukan dengan magnetic stirer sampai terjadi reaksi larutan berubah menjadi seperti stok sabun. Selanjutnya ditambahkan dengan gliserin, alkohol 96\%, sukrosa dan TEA (Trietanolamin). Kemudian dipanaskan pada suhu $60-70{ }^{\circ} \mathrm{C}$ dalam beaker glass $250 \mathrm{ml}$ selama 30 menit sambil diaduk perlahan menggunakan batang pengaduk sampai terbentuk larutan sabun yang transparan, kemudian ditambahkan kolagen tulang sapi selanjutnya sabun didinginkan hingga suhu $40^{\circ} \mathrm{C}$ dan oleum citri, diaduk kembali hingga rata dan dimasukkan kedalam cetakan dibiarkan sampai dingin dan mengeras, kemudian dikeluarkan formula sabun dari cetakan maka diperoleh sabun transparan. Sabun transparan kemudian diuji organoleptis, tinggi busa, pH, alkali bebas, minyak mineral, kadar air, stabilitas, serta uji kelembapan kulit dan iritasi pada sukarelawan (Anggraini, et al., 2015).

\section{HASIL DAN PEMBAHASAN}

Hasil isolasi diperoleh 620 gram serbuk kolagen, dari 2.250 gram tulang sapi (Bos sp.), jika dihitung, maka rendamen hasilnya adalah sebesar $27,5 \%$. Analisis gugus fungsi dari kolagen tulang sapi dengan spektrofotometer FTIR yang dapat dilihat pada Gambar 1. Berdasarkan hasil Gambar 1 menunjukkan bahwa didalam sampel terdapat gugus fungsi $-\mathrm{NH}$ dan $-\mathrm{CH}$ alifatis. Keberadaan $\mathrm{NH}$ terletak pada bilangan gelombang $3379,29 \mathrm{~cm}^{-}$ 1 , - $\mathrm{CH}$ pada bilangan gelombang $2924,09 \mathrm{~cm}^{-1}$, $-\mathrm{NH}$ bilangan gelombang $1558,48 \mathrm{~cm}^{-1}$ dan $1419,61 \mathrm{~cm}^{-}$ 1.

Struktur kolagen mempunyai gugus fungsi $\mathrm{NH}$ ditunjukkan oleh vibrasi stretching pada bilangan gelombang 3440-3400 $\mathrm{cm}^{-1}$, sedangkan gugus fungsi $-\mathrm{CH}$ alifatis ditunjukkan oleh vibrasi stretching berada pada bilangan gelombang 2935$2915 \mathrm{~cm}^{-1}$, sedangkan pada daerah sidik jari menunjukkan vibrasi bending gugus $-\mathrm{NH}$ pada bilangan gelombang $1690-1600 \mathrm{~cm}^{-1}$ dan 1575 $1480 \mathrm{~cm}^{-1}$. Vibrasi gugus fungsi $-\mathrm{NH}$ berada pada bilangan gelombang $>3000 \mathrm{~cm}^{-1}$ dan vibrasi gugus fungsi alifatis $-\mathrm{CH}$ berada pada bilangan gelombang $<3000 \mathrm{~cm}^{-1}$ (Alhana, et al., 2015, Kaban, et al., 2018).

Hasil pengujian organoleptis sabun transparan dari kolagen tulang sapi (Bos sp.) perbedaan warna pada berbagai formula, semakin tinggi konsentrasi kolagen tulang sapi, sabun transparan yang dihasilkan semakin putih dan mengurangi ketransparanan sabun. Begitu pula sebaliknya semakin rendah konsentrasi kolagen tulang sapi, sabun transparan yang dihasilkan semakin bening.

Pengujian tinggi busa pada sabun transparan yang diperoleh dari hasil formulasi dilakukan dengan cara pengocokan dan segera diukur tinggi busa terjadi sebagai tinggi busa dari kedua pengukuran ini dianggap sebagai tinggi busa sabun transparan yang diuji. Berdasarkan data pada Tabel 1 menunjukkan bahwa jumlah busa yang dihasilkan sangat banyak adalah F3 dan F5 tetapi banyaknya tidak berhubungan langsung dengan kualitas sabun. Sabun kolagen transparan yang dihasilkan busa lebih banyak akan lebih disenangi oleh konsumen. Pembentukan busa pada penggunaan zat pembersih sesungguhnya tidak begitu penting karena hanya sedikit pengaruhnya pada pembersihan (Sambo, 2016). Sabun digunakan sebagai bahan pembersih kotoran, terutama kotoran yang bersifat lemak dan minyak karena sabun berfungsi sebagai emulgator, dapat mengemulsikan lemak atau minyak (Poedjadi, 1994).

Tabel 1. Hasil uji organoleptis pada sabun transparan dari kolagen tulang sapi(Bos sp.)

\begin{tabular}{|l|l|l|c|}
\hline Formulasi (\%) & Bentuk & Bau & Warna Kuning \\
\hline Fl (Blanko) & Bulat dan keras & Khas Oleum citri & Transparan \\
\hline F2 (0,5\%) & Bulat dan keras & Khas Oleum citri & Kurang transparan \\
\hline F3 (1\%) & Bulat dan keras & Khas Oleum citri & Kurang transparan \\
\hline F4 (2,5\%) & Bulat dan kurang keras & Khas Oleum citri & Kurang transparan \\
\hline F5 (5\%) & Bulat dan kurang keras & Khas Oleum citri & Tidak transparan \\
\hline
\end{tabular}


Tabel 2. Hasil perhitungan pengujian tinggi busa sabun transparan

\begin{tabular}{|c|c|c|c|}
\hline Formulasi (\%) & $\begin{array}{l}\text { Tinggi Busa Sebelum } \\
\text { Pengocokan (ml) }\end{array}$ & $\begin{array}{l}\text { Tinggi Busa Setelah } \\
\text { Dikocok Dibiarkan } 5 \text { Menit }\end{array}$ & $\begin{array}{l}\text { Selisih Tinggi } \\
\text { Busa (ml) }\end{array}$ \\
\hline FI (Blanko) & 100 & 46 & 54 \\
\hline F2 $(0,5 \%)$ & 100 & 45 & 55 \\
\hline F3 (1\%) & 100 & 43 & 57 \\
\hline F4 $(2,5 \%)$ & 100 & 44 & 56 \\
\hline F5 (5\%) & 100 & 43 & 57 \\
\hline
\end{tabular}

Tabel 3. Hasil pengujian pH sabun transparan

\begin{tabular}{|c|c|c|c|}
\hline Formulasi & & Sabun & $\%$ \\
\hline$(\%)$ & $\begin{array}{c}\text { Sesaat Setelah } \\
\text { Pembuatan }\end{array}$ & Setelah 12 Minggu & Penurunan $\mathrm{pH}$ \\
\hline FI (Blanko) & 9,2 & 9,1 & $1,08 \%$ \\
\hline F2 $(0,5 \%)$ & 9,1 & 9,0 & $1,09 \%$ \\
\hline F3 (1\%) & 9,8 & 9,7 & $1,02 \%$ \\
\hline F4 (2,5\%) & 9,1 & 9,0 & $1,09 \%$ \\
\hline F5 (5\%) & 9,5 & 9,4 & $1,05 \%$ \\
\hline
\end{tabular}

Tabel 4. Hasil pengujian alkali bebas sabun transparan

\begin{tabular}{|l|c|c|}
\hline Formulasi ( $\%)$ & Alkali Bebas & Syarat SN \\
\hline FI (Blanko) & $0,05 \%$ & $0,1 \%$ \\
\hline F2 (0,5\%) & $0,06 \%$ & $0,1 \%$ \\
\hline F3 (1\%) & $0,06 \%$ & $0,1 \%$ \\
\hline F4 (2,5\%) & $0,07 \%$ & $0,1 \%$ \\
\hline F5 (5\%) & $0,08 \%$ & $0,1 \%$ \\
\hline
\end{tabular}

Tabel 5. Hasil uji minyak mineral sabun transparan

\begin{tabular}{|l|c|}
\hline \multicolumn{1}{|c|}{ Formulasi $(\%)$} & Hasil Uji Minyak Mineral \\
\hline FI (Blanko) & Negatif \\
\hline F2 $(\mathbf{0 , 5} \%)$ & Negatif \\
\hline F3 $(\mathbf{1} \%)$ & Negatif \\
\hline F4 (2,5\%) & Negatif \\
\hline F5 (5\%) & Negatif \\
\hline
\end{tabular}

Tabel 6. Hasil pengujian kadar air sabun transparan

\begin{tabular}{|l|r|c|}
\hline Formulasi $(\%)$ & Kadar Air & Syarat SNI \\
\hline FI (Blanko) & $6 \%$ & Maksimal $15 \%$ \\
\hline F2 (0,5\%) & $8 \%$ & Maksimal $15 \%$ \\
\hline F3 $(\mathbf{1} \%)$ & $8 \%$ & Maksimal $15 \%$ \\
\hline F4 (2,5\%) & $12 \%$ & Maksimal $15 \%$ \\
\hline F5 (5\%) & $9 \%$ & Maksimal $15 \%$ \\
\hline
\end{tabular}


Penentuan $\mathrm{pH}$ pada sabun transparan hasil dari formulasi ditentukan dengan menggunakan $\mathrm{pH}$ meter. Berdasarkan data pada Tabel 2 menunjukkan bahwa semua sediaan sabun transparan yang dibuat memiliki rentang $\mathrm{pH}$ antara 9,1-9,8 sesaat selesai dibuat dan rentang $\mathrm{pH} \mathrm{9,0-}$ 9,7 setelah 12 minggu penyimpanan ini menunjukkan bahwa semua sediaan tersebut memenuhi syarat karena menurut (SNI 06-35321994) yaitu menunjukkan rentang $\mathrm{pH}$ yang baik adalah 9,0-10,8. Jika sabun pH-nya terlalu basa akan menyebabkan iritasi pada kulit. Yaitu kulit menjadi kasar, kering, gatal-gatal serta kemerahan.

Kadar alkali bebas sediaan sabun transparan dari kolagen tulang sapi (Bos sp.) antara 0,05\%0,08\% pada Tabel 3 belum melebihi syarat Standart Nasional Indonesia (SNI). Kelebihan alkali bebas dalam sabun dapat disebabkan karena konsentrasi alkali yang terlalu pekat atau berlebih pada proses penyabunan. Alkali bebas yang melebihi standar dapat menyebabkan iritasi pada kulit, seperti kulit luka dan mengelupas. Menurut SNI (06-35321994), kadar alkali bebas pada sabun maksimum sebesar 0.1\% (Sari, 2009). Hasil pengujian diatas menunjukkan bahwa sediaan sabun transparan dari kolagen tulang sapi (Bos sp.) masih dalam keadaan yang aman terhadap kulit.

Seluruh sediaan sabun transparan yang diuji memberi hasil yang negatif terhadap adanya minyak mineral seperti yang tertera pada Tabel 4, berarti seluruh sediaan sabun transparan dari kolagen tulang sapi tidak mengandung minyak mineral. Telah diketahui pada reaksi penyabunan terjadi kekeruhan maka busa pada sabun tidak akan terbentuk (Rozi, 2013).

Seluruh sabun transparan dari kolagen tulang sapi (Bos sp.) yang dibuat mempunyai kadar air antara 6\%-12\% seperti yang tertera pada Tabel 5. Hal ini memenuhi syarat kadar air, kadar air maksimal pada sabun adalah $15 \%$ menurut Standar Nasional Indonesia (SNI) (06-3532-1994). Hal ini dapat dimaksudkan agar sabun dihasilkan cukup keras sehingga lebih efisien dan sabun tidak mudah larut dalam air. Kadar air akan mempengaruhi kekerasan dari sabun. Dari data diatas dapat dilihat kadar air sabun transparan terendah pada blanko dan yang tertinggi $\mathrm{F} 4$ dengan kadar air $12 \%$.

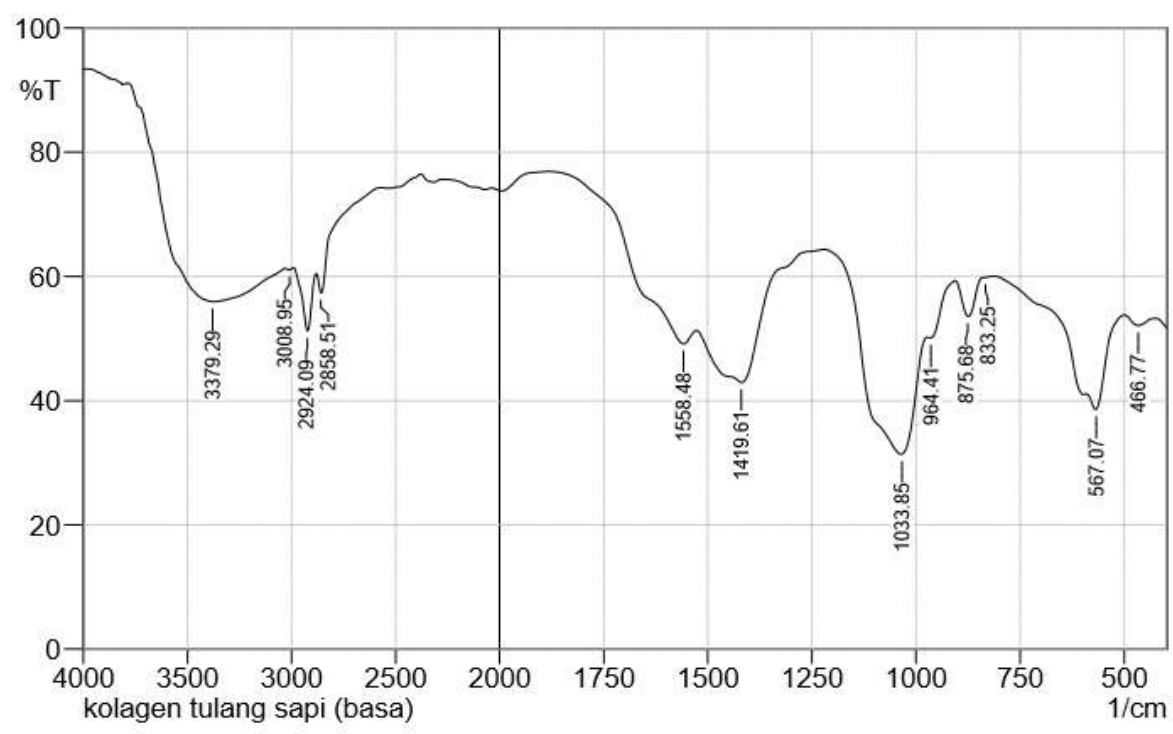

Gambar 1. Spektrum FT-IR Kolagen Tulang Sapi

Hasil dan uji stabilitas dilakukan untuk mengetahui stabilitas sediaan selama penyimpanan, parameter yang diamati dalam uji kestabilan fisik ini meliputi perubahan bentuk, warna adan bau sediaan. Pengamatan bentuk, diperoleh hasil bahwa seluruh sediaan sabun transparan dari kolagen tulang sapi (Bos sp.) yang dibuat tidak terjadi perubahan bentuk dari awal percetakan hingga selama penyimpanan 90 hari dalam suhu kamar. Berdasarkan Tabel 6 menunjukkan bahwa, dari hasil pengamatan warna, seluruh sediaan yang dibuat tetap stabil selama penyimpanan pada suhu kamar selama 90 hari pengamatan. Sabun transparan dengan konsentrasi blanko memberikan warna kuning transparan, konsentrasi $0,5 \%$ memberikan warna 
kuning kurang transparan, konsentrasi 1\% memberikan warna kuning kurang transparan, konsentrasi 2,5\% memberikan warna kuning kurang transparan dan konsentrasi 5\% memberikan warna kuning tidak transparan. Sedangkan bau yang dihasilkan dari seluruh sediaan sabun transparan kolagen tulang sapi (Bos sp.) adalah bau khas yang digunakan yaitu Oleum citri. Bau sediaan tetap stabil dalam penyimpanan 90 hari pengamatan pada suhu kamar (Zebua, et al., 2018).

Penentukan kemampuan formula sabun transparan dalam melembabkan kulit dilakukan terhadap 25 orang sukarelawan berjenis kelamin perempuan dengan usia 20-30 tahun. Berdasarkan data pada Tabel 7 menunjukkan bahwa sediaan sabun transparan dari kolagen tulang sapi (Bos sp.) memberikan hasil "lembab" hingga "sangat lembab". Berdasarkan referensi dari alat Skin moisture analyzer dinyatakan jika lebih dari $40 \%$ kurang lembab, 40-60\% lembab dan lebih besar dari $60 \%$ sangat lembab. Sabun transparan dari kolagen tulang sapi (Bos sp.) yang terbaik adalah F3 yaitu sediaan sabun transparan dari kolagen tulang sapi (Bos sp.) konsentrasi 1\% dengan nilai kelembaban 60,28\% yaitu kategori "sangat lembab" Semakin tinggi konsentrasi tepung kolagen yang ditambahkan pada sediaan sabun transparan maka semakin tinggi pula kemampuan sediaan untuk kelembabkan kulit.

Hasil dan uji iritasi terhadap kullit sukarelawan yang dilakukan pada 10 orang penelis yaitu wanita berusia 20-30 tahun, berbadan sehat jasmani dan rohani, tidak memiliki riwayat penyakit alergi dan menyatakan kesediaannya dijadikan sukarelawan, masing-masing sukarelawan diberi sabun dengan 4 konsentrasi. dengan cara mengoleskan sediaan sabun pada kulit belakang telinga, parameter iritasi yang diamati yaitu adanya kemerahan, gatal-gatal serta kulit menjadi kasar setelah pengujian selama 24 jam (Nazliniwaty, et al, 2016). Uji ini dilakukan untuk melihat keamanan sediaan sabun transparan sebelum digunakan dan untuk mengetahui respon tuhuh manusia secara umum terhadap sabun transparan dari kolagen tulang sapi (Rozi, 2013). Berdasarkan data pada Tabel 8 menunjukkan bahwa semua panelis tidak menunjukkan reaksi terhadap parameter uji iritasi. Dari hasil uji iritasi tersebut dapat disimpulkan bahwa semua sediaan sabun transparan dari kolagen tulang sapi (Bos sp.) yang dibuat tidak menyebabkan iritasi pada kulit.

Tabel 7. Data hasil uji stabilitas sabun transparan

\begin{tabular}{|c|c|c|c|c|c|c|c|c|c|c|c|c|c|c|c|}
\hline \multicolumn{16}{|c|}{ Pengamatan Sediaan } \\
\hline Pengamatan & & Ber & & & arna & unir & & & Oleun & citri & & & & & \\
\hline (hari) & F1 & F2 & F3 & F4 & F5 & F1 & F2 & F3 & F4 & F5 & F1 & F2 & F3 & F4 & F5 \\
\hline 5 & $b$ & $b$ & b & $b$ & $b$ & $t$ & $\mathrm{kt}$ & $\mathrm{kt+}$ & $\mathrm{kt++}$ & $\mathrm{tt}$ & bk & bk & bk & bk & bk \\
\hline 10 & b & $\mathrm{b}$ & b & $\mathrm{b}$ & $b$ & $t$ & $\mathrm{kt}$ & $\mathrm{kt+}$ & $\mathrm{kt++}$ & $\mathrm{tt}$ & bk & bk & bk & bk & bk \\
\hline 15 & $b$ & $b$ & b & $b$ & $b$ & $t$ & $\mathrm{kt}$ & $\mathrm{kt+}$ & $\mathrm{kt++}$ & $\mathrm{tt}$ & bk & bk & bk & bk & bk \\
\hline 20 & $b$ & $b$ & $b$ & $b$ & $b$ & $t$ & $\mathrm{kt}$ & $\mathrm{kt+}$ & kt++ & $\mathrm{tt}$ & bk & bk & bk & bk & bk \\
\hline 25 & $b$ & $b$ & $b$ & $b$ & $b$ & $t$ & $\mathrm{kt}$ & $\mathrm{kt+}$ & $\mathrm{kt++}$ & $\mathrm{tt}$ & bk & bk & bk & bk & bk \\
\hline 30 & $b$ & $b$ & b & $b$ & $b$ & $t$ & $\mathrm{kt}$ & $k t+$ & $\mathrm{kt++}$ & $\mathrm{tt}$ & bk & bk & bk & bk & bk \\
\hline 35 & $b$ & $\mathrm{~b}$ & b & $b$ & $b$ & $t$ & $\mathrm{kt}$ & $\mathrm{kt+}$ & $\mathrm{kt++}$ & $\mathrm{tt}$ & bk & bk & bk & bk & bk \\
\hline 40 & $b$ & $b$ & b & $b$ & $b$ & $t$ & $\mathrm{kt}$ & $\mathrm{kt+}$ & $\mathrm{kt++}$ & $\mathrm{tt}$ & bk & bk & bk & bk & bk \\
\hline 45 & $b$ & $b$ & $b$ & $b$ & $b$ & $t$ & $\mathrm{kt}$ & $\mathrm{kt}+$ & kt++ & $\mathrm{tt}$ & bk & bk & bk & bk & bk \\
\hline 50 & $b$ & $b$ & $b$ & $b$ & $b$ & $t$ & $\mathrm{kt}$ & $\mathrm{kt}+$ & $\mathrm{kt++}$ & $\mathrm{tt}$ & bk & bk & bk & bk & bk \\
\hline 55 & $b$ & $b$ & $b$ & $b$ & $b$ & $t$ & $\mathrm{kt}$ & kt+ & kt++ & $\mathrm{tt}$ & bk & bk & bk & bk & bk \\
\hline 60 & $b$ & $b$ & $\mathrm{~b}$ & $\mathrm{~b}$ & $b$ & $\mathrm{t}$ & $\mathrm{kt}$ & $\mathrm{kt+}$ & $\mathrm{kt++}$ & $\mathrm{tt}$ & bk & bk & bk & bk & bk \\
\hline 70 & $b$ & $b$ & $b$ & $b$ & $b$ & $t$ & $\mathrm{kt}$ & $\mathrm{kt+}$ & $\mathrm{kt++}$ & $\mathrm{tt}$ & bk & bk & bk & bk & bk \\
\hline 80 & $b$ & $b$ & b & $b$ & $b$ & $t$ & $\mathrm{kt}$ & $\mathrm{kt+}$ & $\mathrm{kt++}$ & $\mathrm{tt}$ & bk & bk & bk & bk & bk \\
\hline 90 & b & $\mathrm{b}$ & $b$ & $\mathrm{~b}$ & b & $\mathrm{t}$ & kt & $\mathrm{kt+}$ & $\mathrm{kt++}$ & $\mathrm{tt}$ & bk & bk & bk & bk & bk \\
\hline
\end{tabular}

Keterangan:

$\begin{array}{ll}\text { KTS } & \text { : Kolagen Tulang Sapi } \\ \text { F1 } & \text { : Blanko } \\ \text { F2 } & \text { : KTS }(0,5 \%) \\ \text { F3 } & \text { : KTS }(1 \%)\end{array}$



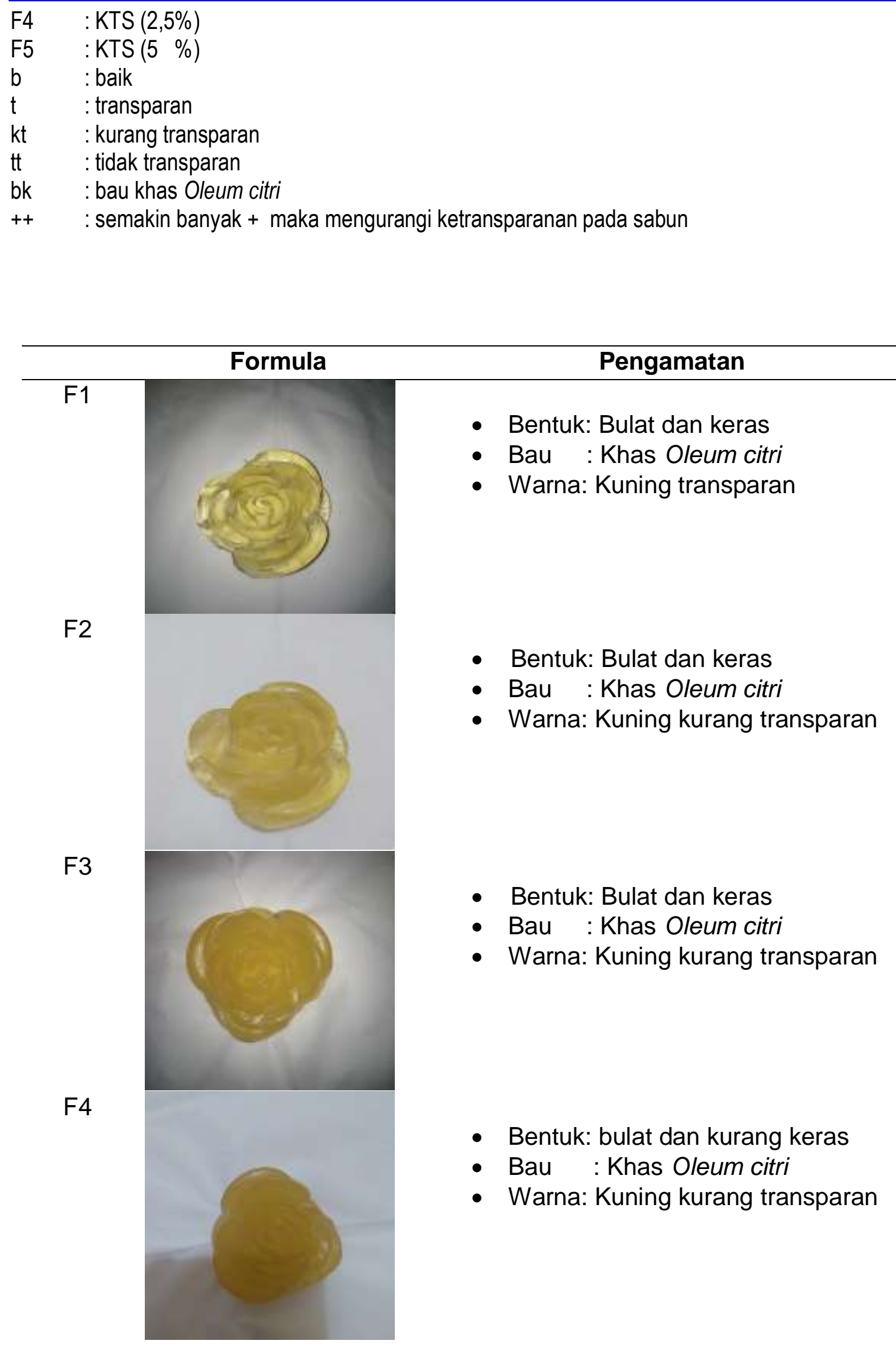
F5

- Bentuk : bulat dan kurang keras

- Bau : Khas Oleum citri

- Warna : Kuning tidak transparan

Gambar 2. Hasil Uji Organoleptis Sabun Transparan Kolagen Tulang Sapi (Bos sp.)

Tabel 8. Hasil uji keseluruhan rata-rata kelembaban kulit sebelum dan sesudah menggunakan sabun transparan

\begin{tabular}{|l|cc|c|}
\hline $\begin{array}{c}\text { Formulasi } \\
\text { KTS }\end{array}$ & $\begin{array}{c}\text { Persentase Kelembapan } \\
\text { Sebelum Perlakuan }\end{array}$ & $\begin{array}{c}\text { Persentase Kelembapan } \\
\text { Sesudah Perlakuan }\end{array}$ & $\begin{array}{c}\text { Skala } \\
\text { Kelembapan }\end{array}$ \\
\hline FI (Blanko) & 35,18 & 52,72 & Lembab \\
\hline F2 (0,5\%) & 32,52 & 56,34 & Lembab \\
\hline F3 (1\%) & 45,86 & 60,28 & Sangat Lembab \\
\hline F4 (2,5\%) & 55,10 & 71,50 & Sangat Lembab \\
\hline F5 (5\%) & 39,82 & 71,26 & Sangat Lembab \\
\hline
\end{tabular}

Keterangan:

Kurang lembab $\quad:<40 \%$

Lembab

$: 40-60 \%$

Sangat lembab

: > $60 \%$

Tabel 9. Hasil uji iritasi terhadap kulit sukarelawan

\begin{tabular}{|c|c|c|c|c|c|c|c|c|c|c|c|c|}
\hline \multirow[t]{2}{*}{ No. } & \multirow[t]{2}{*}{ Penyataan } & \multirow[t]{2}{*}{ Formula \% } & \multicolumn{10}{|c|}{ Sukarelawan } \\
\hline & & & 1 & 2 & 3 & 4 & 5 & 6 & 7 & 8 & 9 & 10 \\
\hline \multirow[t]{5}{*}{1} & Kemerahan & F1 & - & - & - & - & - & - & - & - & - & \\
\hline & & F2 & - & - & - & - & - & - & - & - & - & \\
\hline & & F3 & - & - & - & - & - & - & - & - & - & \\
\hline & & F4 & - & - & - & - & - & - & - & - & - & \\
\hline & & F5 & - & - & - & - & - & - & - & - & - & \\
\hline \multirow[t]{5}{*}{2} & Gatal-Gatal & F1 & - & - & - & - & - & - & - & - & - & \\
\hline & & F2 & - & - & - & - & - & - & - & - & - & - \\
\hline & & F3 & - & - & - & - & - & - & - & - & - & \\
\hline & & F4 & - & - & - & - & - & - & - & - & - & \\
\hline & & F5 & - & - & - & - & - & - & - & - & - & - \\
\hline \multirow[t]{5}{*}{3} & Kulit menjadi kasar & F1 & - & - & - & - & - & - & - & - & - & \\
\hline & & F2 & - & - & - & - & - & - & - & - & - & \\
\hline & & F3 & - & - & - & - & - & - & - & - & - & \\
\hline & & F4 & - & - & - & - & - & - & - & - & - & \\
\hline & & F5 & - & - & - & - & - & - & - & - & - & \\
\hline
\end{tabular}


Keterangan:

KTS :Kolagen Tulang Sapi

F1 : Blanko

F2 : KTS $(0,5 \%)$

F3 : KTS $(1 \%)$

F4 : KTS $(2,5 \%)$

F5 : KTS $(5 \%)$

- : Tidak ada reaksi

$+\quad$ : Kemerahan

+ : : Gatal-gatal

$++\quad$ : Kulit menjadi kasar

\section{KESIMPULAN}

Kolagen dari tulang sapi diperoleh dari tulang sapi dengan rendemen $27,5 \%$ dan dapat diformulasikan kedalam sediaan sabun transparan. Hasil evaluasi mutu fisik sediaan yang dihasilkan memenuhi persyaratan Standart Nasional Indonesia (SNI). Formula terbaik sabun transparan dari kolagen tulang sapi (Bos sp.) untuk melembabkan kulit dalam kategori "sangat lembab" adalah F3 yang mengandung kolagen tulang sapi (Bos sp.) 1\%.

\section{UCAPAN TERIMA KASIH}

Terima kasih kepada Fakultas Farmasi Universitas Tjut Nyak Dhien dan Yayasan APIPSU yang telah memfasilitasi penelitian ini.

\section{REFERENSI}

Alhana, Suptijah, P., Tarman, K. 2015. Ekstraksi dan Karakterisasi Kolagen dari Daging Teripang Gamma. JPHPI, 18(2):150-161.

Anggraini, T., Ismanto S.D. dan Dahlia. 2015. The Making of Transparent Soap From Green Tea Extract, International Journal on Advanced Science Engineering Information Technology, 5(4): 349-356.

Hambali, E., Bunasor, T. K., Suryani, A., Kusumah, G. A. 2005. Aplikasi Dietanolamida dari Asam Laurat Minyak Inti Sawit pada Pembuaran Sabun Transparan. Jurnal Teknik Pertanian. Vol. 15(2).46-53. Fakultas Teknologi Pertanian; Bogor.

Harris, MV., Darmanto, YS., Riyadi, PH. 2016. Pengaruh kolagen tulang ikan air lat yang berbeda terhadap karakteristik fisik dan kimia sabun mandi padat. Jurnal. Peng dan Biotek Hasil Pi. 5(1):118-124

Nagai T, Izumi M, Ishii M. 2004. Fish scale collagen. Preparation and partial Characterization. J. Food Sci and Tech. 39:239-244

Nagai T dan Suzuki N. 2000. Isolation of collagen from fish waste material-skin, bone and fins. J Food Chem. 68: 277-281

Nazliniwaty, Karsono, Zebua, NF., dan Nerdy. Ethanol extract grapefruit peel (Citrus maximaMurr.) gel formulations with gelling agent durian seed gum and carboxy methyl cellulose, Der Pharma Chemica, 2016, 8(20):207-213

Poedjadi, A. 1994. Dasar-dasar Biokimia. Penerbit UI Press. Halaman 81

Rozi. 2013. Formula Sediaan Sabun Transparan Minyak Atsiri Jeruk Nipis (Citrus Aurantifolia) Dengan Cocomid DEA Sebagai Surfaktan. Jurnal Farmasi Universitas Muhammadiyah Surrakarta. Halaman 6-9

Sari. 2009. Pembuatan Sabun Padat dan Sabun Cair Dari Minyak Jarak. Jurnal Teknik Kimia. Universitas Sriwijaya. Palembang. Halaman 29.

Standar Nasional Indonesia, 06-3532-1994. 1994. Standar Mutu Sabun Mandi. Dewan Standarisasi Nasional. Jakarta. Halaman 1 10.

Widyasanti, A. dan Hasna, A.H. 2016, Kajian Pembuatan Sabun Padat Transparan Basis Minyak Kelapa Murni dengan Penambahan Bahan Aktif Ekstrak Teh Putih, Jurnal Penelitian Teh dan Kina, 19(2): 179-195.

Zebua, NF., Putra, ED, Harahap, U, dan Kaban, J. 2018. Durian Seed Utilization As A Base Material Of Topical Gel. Asian Journal of Pharmaceutical and Clinical Research. 11(1):174-177.

Kaban, J., Reveny, J., Tarigan, J., Zebua, NF., 2018. Sulfation Of Palm Seed (Arenga Pinnata Merr.)Galactomannan: Antimicrobial Activity and Toxicity Test. Rasayan Journal of Chemistry. 11(1):294299. 